\title{
Vintage facilities need creative funding
}

W.R. GOMES

Vice President

Agriculture and Natural Resources
(As California Agriculture celebrates its 50th year of publication, we revisit topics originally raised by former UC President Robert Gordon Sproul, in a commentary published in the first issue of December, 1946. - Editor)

"... the growing demands of the agricultural industry, mean of course, that more men [sic] are needed for research, and in turn, more buildings to house them. Fortunately, money is available to care for immediate needs, in the sum of more than seven and one-half million dollars." - former UC President Robert Gordon Sproul in the first California Agriculture, 1946

Sproul described an enviable situation in 1946. A prosperous, peacetime economy favored major expansion in education. UC would soon open its doors to a massive influx of returning Gl's. The mandate was clear, and relatively few social programs competed with education for the public dollar.

UC's College of Agriculture was then embarking on nearly a dozen major construction projects on three campuses. That construction would help create a research and extension enterprise without equal.

Today the Division of Agriculture and Natural Resources is the largest research and extension program in the world, and one of the most highly regarded. Its scientists have advanced food production and environmental science for 120 years. The effects are widespread, ranging from model production methods applied in third world countries to biotechnology innovations that are revolutionizing food production and pest management around the world.

But today - 50 years after Sproul's remarks - that research enterprise is largely housed in buildings of 1950 s vintage and earlier. The building boom of the late 1940s and 1950 s was never repeated.

Many of our research and extension facilities on campuses and in the Research and Extension Centers are in poor condition, inefficient and inadequate to meet current needs. These buildings conform to decades-old building, fire, life safety and accessibility codes. They were built to accommodate the research and engineering laboratory functions of the $1950 \mathrm{~s}$ and earlier - functions which are dramatically more complex today.

In the oldest buildings, there are severe deficiencies in wiring, ventilation, and utilities. These buildings can't be rehabilitated because there is no space in the ceilings for utilities. The laboratory benches are not large enough or well-enough equipped to support contemporary research teams. Facilities do not permit proper disposal of toxic chemicals. Fire exits are inadequate and there is no access for the disabled.

The state's economy and debt capacity limit its present ability to support construction needs. As part of an overall UC effort, the Division has intensively pursued private fund raising for capital projects and made increased use of debt financing, lease-purchase mechanisms and land-lease arrangements with third-party developers. Projects today have multiple fund sources and reflect creative funding approaches.

For instance, the recent construction of the Kearney Agricultural Center's postharvest evaluation facility was funded through a unique agreement involving private and public sources. Though the facility was one of UC's top priority items for capital improvement, its construction was delayed by the lack of state funding. A San Joaquin Valley grower offered to construct a portion of the facility using private funds, in anticipation that a future bond issue would allow state-funded completion. UC licensed the land to the grower who partially constructed and gifted the facility back to the University. The donor's portion was completed in 1992, with the total facility completed in 1994.

Another example is the Lindcove Research and Extension Center, which houses a state-of-the-art research facility duplicating nearly all conditions encountered in commercial citrus packinghouses. The Citrus Research Board Fruit Quality Evaluation Center was constructed by the Board, using the model agreement from Kearney, and donated to UC in 1995.

At the Shafter Research Station, a program was established involving four-way cooperation among the California cotton industry (through California Crop Improvement Association), the U.S. Department of Agriculture (USDA), Kern County and the University to develop and maintain a modern cotton research facility.

Although many Division scientists are housed in laboratories and research facilities of 1950 s vintage or earlier, they are competing in a world where state-of-the-art design is essential to good science.

While there are examples of modern, state-of the art facilities available to our scientists (USDA and the State of California are in the process of providing alternative pest control quarantine and containment facilities at the Riverside and Davis campuses) the Division and those it serves are in dire need of modernized facilities across the state.

Through alliances with our partners in industry and our private supporters, we must continue to develop creative ways of building facilities that allow our scientists to fulfill their world-class abilities. 